\title{
LECTINS FOR THE DETECTION OF IgM ANTIBODIES TO T. GONDII IN THE DIAGNOSIS OF ACUTE TOXOPLASMOSIS BY IMMUNOFLUORESCENCE TEST.
}

I. 'T. I. NOJIMOTO (1), S. HOSHINO-SHIMIZU (2), T. K. NAGASSE-SUGAHARA (1)

\& M. E. CAMARGo (1)

\begin{abstract}
S U M M A R Y
Lectins were labeled with fluorescein and tried as conjugates in the immunofluorescence (IF) test for the detection of IgM antibodies to T. gondii, in the diagnosis of acute toxoplasmosis. This approach was an attempt to find alternative reagents for anti-human IgM fluorescent conjugates (AHIgMFC), which contain quite frequently anaibodies to toxoplasma, as contaminants, due to natural T. gondii infections among animals used for imunization. Lentil (Lens culinaris) lectin fluorescence conjugates (LcFC) provided most satisfactory results. The evaluation of LcFC carried out in a total of 179 sera from patients with acute and chronic toxoplasmosis, with non-related infections or healthy subjects, gave high values of relative efficiency, co-positivity and co-negativity indices, respectively $0.989,0.969$ and 1.000 , in reference to the conventional AHIgMFC. Moreover, three batches of LcFC successively prepared gave reproducible test results. The advantage of $\mathrm{LCFC}$ as an alternative reagent for the serodiagnosis of acute toxoplasmosis is supported by practical aspects of its preparation.
\end{abstract}

KEY WORDS: Anti-IgM detection; Lectins; Acute toxoplasmosis; Lectin conjugate.

\section{N T R O D U G T I O N}

One of the main serologic markers for the acute toxoplasmosis is the presence of IgM anti-toxoplasma antibodies in serum. To detect such antibodies, immunofluorescence tests are widely used because easy to perform. Although presenting limitations of sensitivity and specificity, these can be overcome by relatively simple procedures of removing the interfering factors, such as rheumatoid factor, with immunosorbents 3 and IgG antibodies to toxoplasma, with protein $\mathbf{A}^{6}$, which afford a high reliability to the immunofluorescence assay.
A basic reagent for the IgM-immunofluorescence test is a specific anti-human IgM fluorescent conjugate (AFIgMFC), usually obtained by labeling with fluorochrome the IgG fraction of immunized animal serum, anti-human IgM. Quality of such conjugates differ considerably, not only in respect to the characteristics of specificity and affinity of the produced antibodies but also, by the usual presence of contaminating anti-toxoplasma antibodies. These are due to frequent infections by Toxoplasma gondii of animals as goats, sheeps or rabbits, commonly used for antiserum production. This problem is found even

(1) Instituto de Medicina Tropical de São Paulo, Brasn.

(2) Faculdade de Ciências Farmacêuticas da Universidade de São Paulo, Brasil.

Aduress for correspondenee: Dra. Sumie Hoshiro-Shimizu. Faculdade de Ciências Farmacêuticas da USP. Av. Prof. Lineu Prestes, 580 - Bloco A - Conjunto das Químicas, Cidade Universitária. CEP 05508 São Paulo, SP, Brasil. 
NOJMYTO, I. T. I.; HOSHINO-SHIMIZU, S.; NAGASSE-SUGAFARA, T. K. \& CAMARGO, M. E. - Lectins for the detection of IgM antibodies to T. gondil in the diagnosis of acute toxoplasmosis by immunofluorescence test. Rev. Inst. Med. trop. São Paulo, 29:354-360, 1987.

for products furnished by leading manufacturers.

Some lectins present a much higher affinity for IgM than to the other immunoglobulins 7,20 . Also, T. gondii tachyzoites do not present membrane sugar receptors for most known lectins ${ }^{13}$. In thsi way fluorescent conjugates of lectins were studied as alternative reagents to fluorochrome-labeled anti-IgM antibodies, in the detection of anti-toxoplasma IgM antibodies in serum. In spite of large applications in immunological, biological, chemical and even clinical researches 19 , it seems that lectins have not been previously employed in the detection of antibodies for diagnostic purposes.

\section{MATERIAL AND METHODS}

Serum samples - The study was performed in a total of 179 serum samples, 64 of which presenting a serological patern of acute toxoplasmosis (pattern I), 26 with pattern II or III, corresponding to older toxoplasma infections, 40 from clinically healthy individuals and, 49 from patients with nonrelated infections, including 10 cases of Chagas'disease, 10 of malaria, 10 of mucocutaneous leishmaniasis, 11 of schistosomiasis mansoni and 8 of rheumatoid arthritis. Toxoplasmosis serol. ogic patterns were established according to previous published criteria 4,5 , on the basis of results of a battery of tests, including IgM and IgG-immunofluorescence (IgM-IF and IgG-IF), passive hemagglutination (HA) and complement fixation (CF) tests, performed as described 4.

Toxoplasma antigens - T. gondii tachyzoites' were obtained from mouse peritoneal exsudates two days after inoculation of parasites and TG-180 sarcoma cells, as described 2. After agglutinating the peritoneal cells with phytohemagglutining $\mathbf{P}$ and filtration in nylon wool, purified parasites were treated with formalin 13 .

Lectin fluorescent conjugates (LFG) Five commercially available lectins (Sigma) Chem. Co., St. Louis, USA) from Lens culinaris, Phaseolus vulgaris, Glycine max, Arachis hypogea and Canavalia ensiformis, were tested, for selecting the most adequate in detecting IgM antibodies.

For the study, three batches of lentil (Lens culinaris) lectins (I, II and III) were then prepared in large amounts, following the technique of HOWARD \& SAGE 14,15 and one batch of Con A (Canavalia ensiformis) as described .

Lectins were labeled with fluorescein isothiocyanate according to CLARK \& SHEPARD 8 and lectin protein concentration determined by LOWRY et al method ${ }^{17}$ 'with crystalline bovine albumin (Sigma Chem. Co., St. Louis, USA) as standard.

Activity of lectins - All the lectins were characterized by their ability in agglutinating formalinized, group 0, human red blood cells. Quantitative assays were performed in plastic microtiter plates with, V-shaped wells. To 0.05 $\mathrm{ml}$ two-fold serial dilutions of lectins in $0.01 \mathrm{M}$ phosphate buffered saline solution at pH 7.2 (PBS), stating from 1:2, $0.025 \mathrm{ml} 2 \%$ erytrrocytes suspension in .PBS were added. Sedimentation patterns were read as usually, after 90 minutes, at room temperature.

Immunofluorescence (IF) test - Conven. tional assays for IgM-IF and IgG-IF were carried out as described ${ }^{4}$ using commercial ( $\mathrm{Hy}$ land Div. Travenol Lab., California, USA) fluorescent anti-human-IgM, $\mu$ chain specific (AHIgMFC) and anti-human IgG, $\gamma$ chain specific (AHIgGFC) conjugates. Monospecificity of these conjugates was confirmed by immu. noelectrophoresis, as well as absence of antiT. gondii antibodies, as determined by immunofluorescence assays. Optimal conditions for tests with lectin fluorescent conjugate (LcFC) were standardized, as later referred. To verify the specificity of LFC, inhibition of IF tests was performed by previous addition of saccharide to the conjugate. Also, to verify the specificity of the interaction between LFC and IgM antibodies, sera showing positive results were treated with 2-mercaptoethanol 9 and retested. To avoid the interference of rheumatoid factors in assays for IgM antibodies, all sera were tested by RA latex agglutination test (Behringwerke AG, Germany) and those giving positive results were absorbed with heat-aggregated human gammaglabulin as recommended ${ }^{3}$. 
NOIMOTO, I. T. I.; HOSHINO-SHIMIZU, S.; NAGASSE-SUGAHARA, T. K. \& CAMARGO, M. E. - Lectins for the detection of. IgML antibodies to $T$. gondil in the diagnosis of acute toxoplasmosis by immunofluorescence test. Rev. Inst. Med. trop. São Paulo, 29:354-360, 1987.

Statistical analysis - To compare results obtained with LFC and AHIgMFC in the IF tests, t-student test and coefficient correlation were utilized according to PAUL \& WHITE and LUTZ 22,18. For the evaluation of LFC tests, relative efficiency, co-positivity and conegativity indices twere estimated ${ }^{10}$.

\section{RESULTS}

A total of 7 lectins were studied, 5 from commercial purchase and 2 prepared in our laboratory, for the standardization of the method.

Protein contents per milliliter and hemag. glutinating titers were respectively: L. culinaris (10.8 $\mathrm{mg}, 1: 512$ ), P. vulgaris (14.8 $\mathrm{mg}, 1: 16$ ), G. $\max (10.8 \mathrm{mg}, 1: 8)$, A. hypogea $(16.0 \mathrm{mg}$, $1: 8)$, C. ensiformis $4.0 \mathrm{mg}, 1: 2$ ), $\mathbf{L}$. culinaris (I) (12.6 mg, 1:2,048), C. ensiformis (I) (5.5 mg, 1:16). The last two (I), locally prepared, presented higher titers in relation to those commercially acquired.

Different conditions of $\mathrm{pH}$, temperature and time were required in the IF test with LFC to obtain comparable titers to those given by the conventional AHIgMFC 4 . Thus, serum samples were incubated with T. gondii antigen at $4^{\circ} \mathrm{C}, 25^{\circ} \mathrm{C}$ and $37^{\circ} \mathrm{C}$ for periods varying from 30 minutes to 27 hours. Best results were seen at $25^{\circ} \mathrm{C}$ (room temperature), from 4 to 27 hours. For technical convenience an incubation period of 24 hours was also Further incubation step with IFC was also assayed and most satisfactory results were obtained for 90 minutes at $37^{\circ} \mathrm{C}$. Influence of pH was studied, best results being obtained by diluting sera in PBS at pH 8.0 and LFC at $\mathrm{pH}$ 7.5, whereas washing of slide preparation in PBS at pH 7.2.

As indicated in Table $\mathrm{I}$, only lentil lectin fluorescent conjugate ( $\mathrm{LCFC}$ ), at the maximum reactivity, detected specifically IgM antibodies to $\mathbf{T}$. gondii in a similar fashion to the reference AHIgMFC. For other lectins, although giving similar titers for IgM antibodies, much weaker fluorescence staining was observed, as well as non-specific reactions with negative sera diluted at 1:16.

\section{T A $\mathbf{D}$ 工 E I}

Comparative titrations with different lectins conjugates of sera from: a) recent $\mathbf{T}$. gondii infection, pattern $I$; b) old T. gondii infection, pattern III; and c) non-infected individual

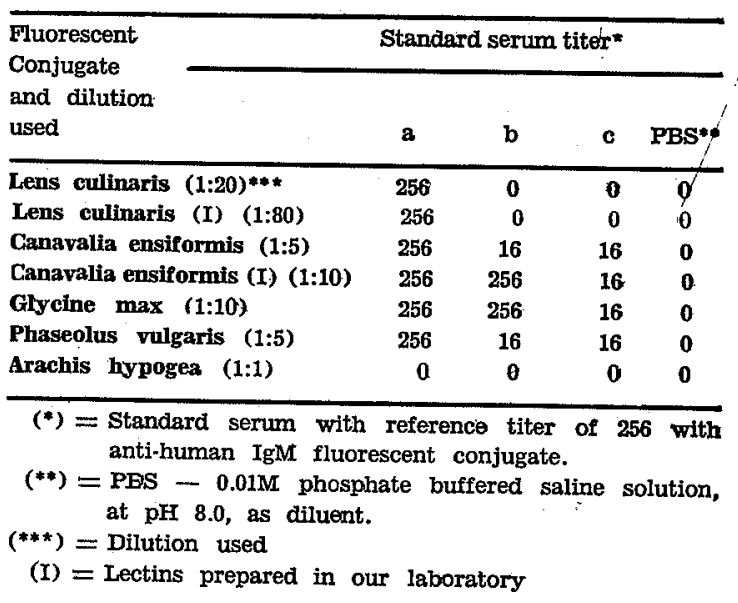

Table II depicts comparative results in the IgM-IF test with Lens culinaris and with anti. IgM antibodies, for 179 serum samples from patients with acute and chronic toxoplasmosis, other diseases and clinically normal individuals.

In comparison with the anti-IgM fluorescent conjugate test, the test carried out with lentil conjugate furnished a co-positivity index of 0.969 , a co-negativity index of 1.000 and a relative efficiency index of 0.989 . In 64 cases total agreement of titers was seen in 42 $(65.6 \%)$, differences of one dilution in 18 $(28.1 \%)$ and of two dilutions in 4 cases (6.3\%). The geometric mean titers for AHIgMFC 'was 8.37 and for $\mathrm{LCFC}$, 7.79. A positive correlation, $r=0.800$, was observed between the IgM antibody titers obtained by both fluorescent conjugates and, accordingly, an equation of regression line could be estimated: $Y=1.1340+0.8394$ (fig, 1). The significance of this value was confirmed by the finding of t-test value of 12.66, in comparison to the critical value of 2.66 , (62 d.f at $1 \%$ level).

Three different batches of LcFC (I, II and III) were prepared in the laboratory for the study of the reproducibility of the reagents. They showed respectively the hemagglutinating titers of 1,024, 2,0448 and 4,096 and dilution of use in the IF test of 1:40, 1:80 and 
NOJMOTO, I. T. I.; HOSHINO-SHIMIZU, S.; NAGASSE-SUGAHARA, T. K. \& CAMARGO, M. E. - Lectins for the detection of IgM antibodies to T. gondil in the diagnosis of acute toxoplasmosis by immunofluorescence test. Rer. Inst. Med. trop. São Paulo, 29:354-360, 1987.

T A B L E II

Comparative results of Lens culinaris and anti-human IgM fluorescent conjugates in IgM-IF tests, performed in 179 serum samples

\begin{tabular}{|c|c|c|c|c|c|}
\hline \multirow{3}{*}{ Diagnosis } & \multirow{3}{*}{$\begin{array}{l}\text { N.o of } \\
\text { serum }\end{array}$} & \multicolumn{4}{|c|}{ Fluorescent conjugate } \\
\hline & & \multicolumn{2}{|c|}{ Lectin } & \multicolumn{2}{|c|}{ Anti-human IgM } \\
\hline & & Positive & Negative & Positive & Negative \\
\hline Acute toxoplasmosis & 64 & 62 & 2 & 64 & $\mathbf{0}$ \\
\hline Chronic toxoplasmosis & 26 & $\mathbf{0}$ & 26 & 0 & 26 \\
\hline Chagas'disease & 10 & $\mathbf{0}$ & 10 & $\mathbf{0}$ & 10 \\
\hline Malaria & 10 & $\mathbf{0}$ & 10 & 0 & 10 \\
\hline Schistosomiasis mansoni & 11 & 0 & 11 & 0 & 11 \\
\hline Mucocutaneous leishmaniasis & 10 & 0 & 10 & 0 & 10 \\
\hline Rheumatoid arthritis & 8 & $\mathbf{0}$ & 8 & $\mathbf{0}$ & 8 \\
\hline Clinically normal individuals & 40 & 0 & 40 & 0 & 40 \\
\hline
\end{tabular}

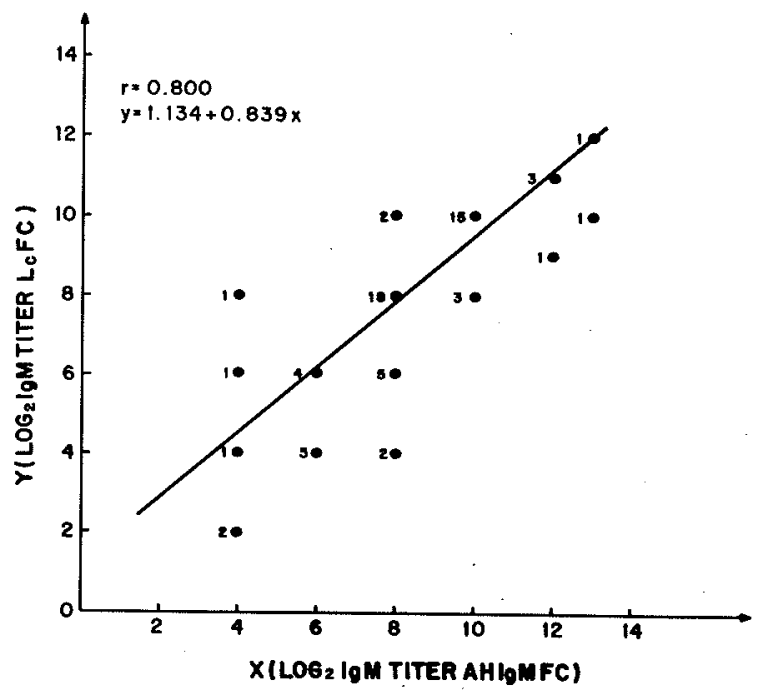

Fig. 1 - Regression of IgM antibody titers detected by lentil lectin fluorescent conjugate (LcFC) against titers obtained by anti-human IgM fluorescent conjugate (AFIgMFC). Numbers along dots correspond to the frequency of titers.

1:160. These results demonstrate possibility of producing fluorescent reagents of good quality with easy in relation to the conventional AFIgMFC.

\section{DISCUSSION}

Results here presented show that lentil lectins labeled with fluorescent isothiocyanate can constitute a satisfactory alternative reagent for the anti-IgM antibody conjugate, in IF test for the detection of anti-toxoplasma IgM antibodies. As sensitive as the antibody conju. gate, lectin conjugates have the advantage of maintaining closely reproducible reactive cha- racteristics among different batches and of beeing free of contaminating anti-toxoplasma antibodies.

Isolation of lentil lectins here processed by gel filtration chromatography on Sephadex G-100; as described by HOWARD et al 14,15, gives a mixture of two active components, A and $B$, 'with similar biological properties $14,15,23$. Both show a molecular weight about 49.000, their hemagglutinating activities can be equally inhibited by d-mannose and d-glucose and, in gel precipitating systems, a line of immunochemical identity is presented by the anti-A and the anti-B immunosera raised in animals. Because of this close relationship, in the present work the $A$ and $B$ lectin components were not further separated in a carboxymethyl cellulose chromatography as recommendea 10 .

Activities of the fluorescent lectin conjugates differed somewhat from those reported for native lectins. For instance, SPENGLER \& WEBER ${ }^{20}$ have found a selective binding of phytohemagglutinin (PHA), a lectin from Phaseolus vulgaris, to IgM of human normal serum. However, we had poor results with this lectin, possibly because we have dealt with IgM antibody combined with antigen. in consequence of modifications in molecular configuration of the immunoglobulin when form. ing immunocomplexes some sugar components could become less exposed.

Carbohydrates were estimated as $12.8 \%$ of the IgM molecules, comprising 7.6 parts of mannose and glucose, 1.4 parts of fucose and sialic acid, and 1.0 part of galactose, in con- 
NOJIMCTO, I. T. I.; HOSHINO-SHIMIZU, S.; NAGASSE-SUGAHARA, T. K. \& CAMARGO, M. E. - Lectins for the detection of IgM antibodies to T. gondii in the diagnosis of acute toxoplasmosis by immunofluorescence test. Rev. Inst. Med. trop. São Paulo, 29:354-360, 1987.

trast to $2.9 \%$ of saccharides in the IgG molecule $11,12,21$. It should then be expected that lectins with affinity to mannose and glucose such as Con A, a lectin from Canavalia ensiformis and lentil lectins, could provide good reagents. However, Con A showed to be less effective than lentil lectins, probably because of factors as molecular size, spacial configuration, $\mathrm{pH}$ and temperature, which might be limiting its interaction with the IgM molecules bound to antigen fixed on microscope slides. For instance, HUET ${ }^{16}$ observed maximal reactivity of Con A at pH 7.0 and $37^{\circ} \mathrm{C}$, conditions that differed from those standardized for our tests.

A previous addition of mannose or glucose to the LcFC inhibited its activity in the IF test. Also, specificity of the conjugate could be indicated by negative results when testing serum samples presenting serologic patterns II or III, corresponding to chronic or pregressive toxoplasma infections, and samples from clinically healthy individuals or cases of non-related diseases. Moreover, positive sera from patients with toxoplasmosis became completly negative after serum treatment with 2-mercaptoethanol.

To obtain sensitive results with lentil lectin conjugates, different factors had to be carefully ascertained, such as $\mathrm{pH}$, temperatures and periods of incubation. For diluents, better results were seen for $\mathrm{pH}$ values above 7.2. Incubation periods required were in general longer than for the reference system, and 24 hours at room temperature was chosen for incubating sera and, 90 minuter at $37^{\circ} \mathrm{C}$ for the conjugate. Besides different physicochemical properties, lentil lectin conju. gates interact with fewer sugar receptors found on IgM molecules than the number of epitopes reacting with labeled anti-IgM antibodies. By lengthening the time of serum incubation more residual antibodies could bind on the antigens, thus rendering a large number of sug. ar receptors to react with the lentil conjugate.

Reliability of the lentil lectin conjugate in the test for anti-toxoplasma antibodies was indicated by the relative efficiency index of 0.989, derived from high co-negativity (1.000) and co-positivity $(0.969)$ indices in relation to the classical IF test. Similarity of results between both kind of conjugates was shown by the close geometric mean titers ( 8.37 for AHIgMFC and 7.79 for LCFC) and by a positive titer correlation of $\mathbf{r}=\mathbf{0 . 8 0 0}$.

It is interesting to note also the similarity between staining patterns of both conjugates, including even the non-specific polar stain ing eventually observed for negative sera.

In this way we conclude on the advantages in using lentil lectins conjugates in the IgM-IF test for toxoplasmosis, instead of animal immune sera derived conjugates, in view of the economical aspects, technical ease in obtaining quite reproducible fluorescent conjugate batches and reliability of test results. Our preliminary results also indicate the pos. sibility of applying the lettins in simlar fashion for enzyme immunoassays for the diagnostic purposes.

\section{RESUMO}

Lectinas para a deteç̧ão de anticorpos IgM anti-T. gondii no diagnóstico da toxoplasmose aguda pela reação de imunofluorescência

Lectinas foram marcadas com fluoresceina e testadas na reação de imunofluorescência para a detecção de anticorpos anti-T. gondii, no diagnóstico da toxoplasmose aguda. Neste estudo tentou-se encontrar reagentes alternativos para conjugados fluorescentes anti-IgM humano (CFAIgMH), que com frequiência contém anticorpos antitoxoplasma, como contaminantes, devido às infecções naturais por $\mathbf{T}$. gondii, entre os animais utilizados para imu. nização.

Conjugados fluorescentes de lectina de lentilha (CFL) (Lens culinaris) forneceram resultados satisfatórios.

Avaliação do CFL efetuada em total de 179 amostras de soros de pacientes com toxoplasmose aguda e crônica, com infecções não relacionadas e de indivíduos sadios, mostrou valores altos nos indices de eficiência relativa, co-positividade e co-negatividade, respectivamente de $0,989,0,969$ e 1,000 , em relação ao CFAIgMH convencional. Além disso, três partidas de CFL preparadas sucessivamente forneceram resultados reprodutiveis. A vantagem. 


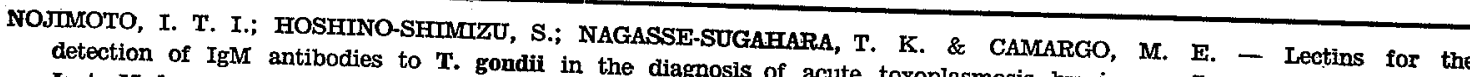
detection of IgM antibodies to T. gondii in the diagnosis of acute toxoplasmosis by immunofluorescence test. Fer.
Inst. Med. trop. São Paulo, 29:354-360, 1987.

de se empregar o LFC como reagente alternativo no diagnóstico sorológico da toxoplasmose aguda consiste nos aspectos práticos da sua preparação.

\section{ACKNOWLEDGEMENTS}

We are grateful for the support received from Fundaçãa dè Amparo à Pesquisa do Esta. do de São Paulo (FAPESP) and from Conselho de Desenvolvimento Científico e Tecnológico (CNPq-PIDE V). Also, we thank to Miss Maria Inês Cardillo and to Almir Robson Ferreira for helping us to prepare the manuscript.

\section{REFERIENCES}

1. AGRaWAL, B. B. I. \& GOLDSTEIN, I. J. - Proteln carbohydrate interaction. VI - Isolation of concana. valin $+A$ by specific absorption on cross-linked dextran gels. Biochim. biophys. Acta. (Amst.), 147: 262-271, 1967.

2. ARDOIN, P.; COUZINNAU, P. \& BAUFINE-DUCROCQ, H. - Sur l'utilization du sarcome TG-180 pour l'obtention d'une suspension riche en Toxoplasma gondil extracellulaires. C.R. Soc. Biol. (Paris), 161: 117-119, 1967.

3. CaMargo, M. E.; LeSER, P. G. \& ROCGA, A. Rheumatoid factors as a cause for false positive IgM anti-toxoplasma fluorescent tests. A technique for specific results. Rev. Inst. Med. trop. S. Paulo, 14: 310-313, 1972.

4. CaMargo, M. E. \& IESER, P. G. - Diagnostic information from serological tests in human toxoplas mosis. II - Evolutive study of antibodies and serological pattern in acquired toxoplasmosis, as detected by hemagglutination, complement fixation, IgG and IgM immunofluorescence tests. Rev. Inst. Med. trop. S. Paulo, 18: 227-238, 1976.

5. CaMargo, M. E.; LESER, P. G. \& LESER, W. S. P. - Definição de perfis sorológicos na toxoplasmose. Importância diagnóstica e epidemiológica. Rev. bras. Pat. clín., 13: 113-127, 1977.

6. CAMARGo, M. E.; LESER, P. G. \& ROCCA, A. Detection of IgM anti-toxoplasma antibodies in acute acquired and congenital toxoplasmosis after protein $A$ treatment of serum. Rev. Inst. Med. trop. S. Paulo. 25: 201-206, 1983.

7. ChatelaIN, C.; LEMOINE, A.; DUGOUYON, J. M.; BLANC, M. \& ROUGL, P. - Interaction of polyclonal and monoclonal human immunoglobulins $G$ with various lectins (Concanavalin $A$, lentil and pea lectins). In EOG-HANSEN, T. C., ed. Lectins, blology, biochemistry, clinical biochemistry. New York, Walter do Gruyter, 1982. v. 2, p. 303-402.
8. ClaRK, H. F. \& ShEPARD, c. C. - A dialysis technique for preparing fluorescent antibody. Virology, 20: $642-644,1863$.

9. DEUTSCH, H. \& MORTON, J. I. - Dissociation of human serum macroglobulins. Selence, 125: 600-601.
1957.

10. GaLleN, R. S. \& GaMBINO, S. R. - Beyond normality. The predictive value and efficiency medical diagnosis. New York, John Wiley, 1975.

11. HEIMBERGER, N.; HEIDE, H.; HAUPT, H, \& SCHULTZE, H. E. - Baustein analysen von human serum proteinen. Clin. Chim. Acta, 10: 293-307, 1964

12. HICKMAN, S.; KORNFELD, R.; OSTERLAND, C. $\mathrm{K}$. \& KORNFELD, $\mathbf{s}$. - The structure of the glycopeptides of a human $\delta \mathrm{M}-$ immunoglobulin. $\mathrm{J}$. biol. Chem., 247 2156-2163, 1972.

13. HOSHINO-SHIMIZU, S.; MLNEO, J. R. \& CAMARGO M. E. - Lectin used in the purification process of Toxoplasma gondii tachyzoites. J. Parasit., 64: 989 $991,1980$.

14. HOWARD, I. IK. \& SAGE, H. J. - Isolation and characterization of a phyto-hemagglutinin from the lectin. Biochemistry, 8: 2436-2441, 1969.

15. HOWARD, I. K.; SAGE, H. J.; STEIN, M. D.; YOUNG, N. M.; LEON, M. A. \& DYCKES, D. F. - Studies on a phytohemagglutinin from the lentil. II - Multiple forms of Lens Culinaris hemagglutinin. J. biol. Chem., 246: 1590-1595, 1971.

16. HUET, M. - Faactors affecting the molecular structure and agglutinating ability of concanavalin $A$ and other lectins. Europ. J. Biochem., 59: 627-632, 1975.

17. LOWRY, O. H.; ROSEBROUGH, N. J.; FARR, A. L. \& RANDALL, R. J. R. - Protein measurement with the folin phenol reagent. J. biol. Chem, 193: 265$271,1951$.

18. LUTZ, w. - Statistical methods as applied to immunological data. In: WEIR, D. M., ed. Handbook of experimental immunology. Oxford, Blackwell Scientific Publications, 1973. p. 1163-1202.

19. PEREIRA, M. E. A. - Lectins. In: ATASSI, $M$. Z. A.; VAN OSS, C. J. \& AESOLON, D. R., ed Molecular immunology. New Yoric, Marcel Dekzker. 1984. p. $319-335$.

20. SPENGLER, G. A. \& WEBER, R. M. - Interactions of PHA with human normal serum proteins. In BOG-HANSEN, T. C., ed., Lectins, biology, biochemistry, elinical biochpmistry. New York, Watter de Gruyter, 1981: p. 231-240.

21. WEINSTEIN, Y.; GIVOT, D. \& STRAUSBAUCH, P H. - The fraction of immunoglobulins with inselu. 


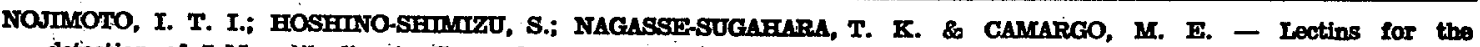
detection of IgMa antibodies to T. gondil in the diagnosis of acute toxoplasmosis by immunofluorescence test. Rev. Inst. Med. trop. Säo Paulo, 29:354-360, 1987.

bilized concanavalin A. J. Immunol., 108: 1402-1404, 1972.

22. WHIFE, C. - Statistical methods in serums surveys. in: PAUL, J. R. \& WHITE, C. - Serological epidemIalogs. New York, Academic Press, 1973. p. 19-32.
23. YOUNG, N. M.; rEON, M. A. \& TAKaFasH, T. Studies on a phytohemagglutinin from the lenth. $J$. biol. Chemn, 246: 1596-1601, 1971.

Recebido para publicactio em $1 / 6 / 87$. 